Journal of Social Sciences 7 (2): 113-119, 2011

ISSN 1549-3652

(C) 2010 Science Publications

\title{
Can Technology Acceptance Model be Applied on the Rural Setting: The Case of Village Development and Security Committee in Malaysia
}

\author{
Bahaman Abu Samah, Hayrol Azril Mohamed Shaffril, \\ Musa Abu Hassan and Jeffrey Lawrence D’Silva \\ Laboratory of Rural Advancement and Agriculture Extension, \\ Institute for Social Science Studies, University Putra Malaysia
}

\begin{abstract}
Problem statement: Malaysia has come out with a number of strategies such as National Information Technology Center, Universal Services Provider, Rural Internet Center and Rural Info Center to strengthen and encourage ICT usage among the rural community. Besides the efforts that are brought by the government, do the rural community especially their leaders which are the Village Development and Security Committee use ICT? Approach: The main objective of this study was to investigate any relationship that might occur between variables of Technology Acceptance Model and ICT usage among Village Development and Security Committee. A total of 240 Village Development and Security Committees were selected as the respondents for this study where a developed questionnaire was used to gain the data needed. For the purpose of analysis, SPSS was used where descriptive and inferential analyses were performed. Results: Based on the analyses run, it can be concluded that Village Development and Security Committee in Malaysia have a moderate level of ICT usage. Further analyses run showed that all of the three variables of Technology Acceptance Model namely attitude, perceive ease of use and perceive usefulness have a positive and significant relationship with ICT usage while attitude was detected as the main contributor towards ICT usage among Village Development and Security Committee. Conclusion/Recommendation: This study has revealed that Technology Acceptance Model that was used to explain ICT usage can be applied within the Malaysian rural setting. It also can be concluded that Village Development and Security Committee with a high level of attitude, perceive ease of use and perceive usefulness towards ICT will have higher level of ICT usage. To further develop and sustain this high level of attitude, perceive ease of use and perceive usefulness towards ICT usage, Village Development and Security Committee must be frequently exposed to ICT information and knowledge. It is recommended that ICT house to house training can be conducted among the Village Development and Security Committee by the related agencies.
\end{abstract}

Key words: Rural development, village leaders, ICT usage, technology acceptance model

\section{INTRODUCTION}

Rural development through ICT development: Rural development strategy was initiated by the government for more than half a century in order to ensure the continuity of development for the rural community. One of the strategies to achieve this developmental goal is to introduce and encourage use of ICT among the rural community. Undoubtedly ICT is indeed an important tool for development. Michiels and Van Crowder (2001) has defined ICTs 'as a range of electronic technologies which when converged in new configurations are flexible, adaptable, enabling and capable of transforming organizations and redefining social relations'. ICT has a lot of benefits to offer such as enhance job performance, diversify tasks, speed up communication, save energy, increase income, increase productivity and many more (Rahman et al., 2005 and Ghazy et al., 2008).

Based on the huge benefits offered by the ICT, there are a number of ICT projects that have been initiated by the government for the purpose of enhancing ICT usage and to reduce the ICT illiteracy among the rural community. The National Information Technology Center (NITC), for example, was established in 2002 in line with IT Policy 2000 under the Ministry Science and Technology (MOST). The main focus of NITC is to create knowledge based society by supporting knowledge based institutions and

Corresponding Author: Bahaman Abu Samah, Laboratory of Rural Advancement and Agriculture Extension, Institute for Social Science Studies, University Putra Malaysia 
industries as well as to promote and develop Information Technology (IT). Universal Service Provider or known as USP is another ICT strategy brought by government. It was initiated in order to ensure the community have full access to the telephone and internet services.

Rural Internet Centre (PID) has been established by the government to provide greater access of ICT to the rural community. PID was initiated in April 2000 by the Ministry of Energy, Water and Communication (MEWC) of Malaysia. Currently, a total of 42 PID centers were established nationwide. The main objective of PID establishment is to narrow down the digital divide between rural and urban communities. The establishment of PID was focused on the rural areas. PID strives to improve ICT infrastructure development, in addition it provides continuous training and encourages local content development. In order to ensure that the rural community posses a high level of ICT skills, continuous trainings and seminars have been conducted by PID. The basic focus of the training is the introduction of computer applications, e-mail usage and website surfing. Another ICT project brought by government is known as Rural Info Center (MID). MID was established with the cooperation of Ministry of Rural and Regional Development (KKLW) through their Infodesa Program. The MID was implemented in order to provide the rural community with ICT facilities and basic ICT trainings. The main objective of MID is to benefit the rural community from the computer and internet utilization in their daily activities. Indirectly, establishment of MID can raise the socio-economic standard of the rural population.

Village Development and Security Committee (VDSC): The establishment of Village Development and Security Committee (VDSC) was in accordance to Order No 3, Plan on Country and Rural Development 1962. The main objective of VDSC is to act as government eye and ear in creating more developed community and strengthening the relationship between the government and the rural community. VDSC as the leaders of the rural community will present whatever the rural community needs and by referring to VDSC, the government will fulfill the rural community needs. Besides, VDSC also is utilized as the government effort to overcome four main problems faced by the rural community namely poverty, health, illiteracy and lackadaisical attitude. VDSC establishment is the evolution of several rural development programs. It was developed based on the government experience in establishing rural development programs such as program of Gerak Maju established in 1966, program of
Jaya Diri established in 1968 and program of Gerak Pembaharuan established in 1972. VDSC has a huge number of members. Based on the recent statistics provided by Department of Community Development (DCD), there are approximately 217, 545 VDSC members across the country. Even though the number of VDSC members is huge, are all of the VDSC members as the leaders of the rural community are ICT literate? If not, they should be equipped with relevant ICT skills and knowledge as one of the government efforts to achieve zero ICT illiteracy.

Technology acceptance model: There are a number of existing prominent theoretical models that explain specifically the usage of ICT. One of its is the Technology Acceptance Model (TAM). This model which is an adaptation to the Theory of Reasoned Action (Fishbein and Ajzen, 1975) was further developed by Davis et al. (1989). TAM is designed to explain determinants of user acceptance of a wide range of end-user computing technologies (Davis et al., 1989). In addition, TAM is not only parsimonious but also can provide empirical support to explain determinants of ICT usage (Agarwal and Prasad, 1999). It claims that user's adoption of ICT is determined by intention to use, which in turn is driven by the user's attitude and belief about the system. TAM further explains that perceived usefulness and perceived ease of use are helpful in explaining difference in users' intention (Davis et al., 1989). In short, it can be concluded that TAM emphasizes on three factors that can influence usage of technology, namely attitude, perceive usefulness and perceive ease of use. Attitude is a mental and neural state of readiness, organized through experience. Exerting a directive or dynamic influence upon the individual's response to all objects and situations with which it is related (Horne, 1985). Davis et al. (1989) defined perceived usefulness as the degree to which a person believes that using a particular information systems would enhance his or her job performance. In this study, perceived usefulness is defined to the extent to which VDSC members believe that ICT usage would be useful. Conversely, Davis et al., (1989) defined perceived ease of use as the degree to which a person believes that using a particular information system would be free of effort.

Can attitude, perceive ease of use and perceive usefulness influence ICT usage? There are lot of previous studies that have showed positive relationship between attitude and ICT usage (Chau, 2001; Shiro, 2008; Dixon, 2009). Attitude is indeed one of dominant factors towards ICT acceptance and ICT usage. Positive 
attitude usually will lead to increase ICT usage while negative attitude will results in reluctant to use ICT (Zhang and Aikman 2009). This finding is further supported by Mahmood et al. (2000) where they stressed that attitude is an important part of ICT usage mainly because a positive attitude is usually an indicative of technology acceptance, thus will strengthen the people believe that ICT will assist and enhance his or her tasks performance. According to Meso and Musa (2008), perceived usefulness and perceived ease of use, greater reliability of the technology and easier access to ICT are the factors that contribute towards greater use of ICT. Furthermore, the available literatures provide evidence on the influence of perceived usefulness on intention to use ICT (Venkatesh and Morris, 2000; Argawal and Prasad, 1999). Besides, there has been extensive research that explore the relationship between perceived ease of use and intention to use ICT (Venkatesh and Davis, 1996). Interestingly, when a community perceived that ICT is useful, it will create a sustainable usage of ICT among the community (Rogers, 2003). Rogers (2003) furthermore explained that the perceived benefits must exist and continuous. In order for ICT to be perceived useful it must be low cost, has the ability to reach wider market, able to gather large information within a short time and lower cost of sending email (Laudon and Laudon, 2000).

\section{MATERIALS AND METHODS}

A total of 240 VDSC were selected as the respondents. The respondents selected represent four states in Malaysia namely Kedah, Perak, Terengganu and Johor. Results of the pilot study revealed a high level of reliability of the four instruments-ICT usage, perceived ease of use, perceived usefulness and attitude towards ICT. The Cronbach alpha value ranged from 0.92-0.99 which exceeded the threshold of 0.70 (Nunally, 1978). Data were gathered through face to face interview which took 20-30 minutes to be completed. Ten point likert-like scale was employed for each of the four instruments where 1 representing very low and 10 representing very high. Data were analyzed using SPSS for both descriptive and inferential analyses. Descriptive statistics used include frequency, percentage, mean and standard deviation while the inferential statistics used include Pearson productmoment correlation and Multiple Linear Regression. These two statistics were used to determine relationship between independent variables and ICT usage. The independent variables comprise attitude, perceive ease of use and perceive usefulness. ICT usage refers to computer and internet usage for administration works among VDSC members.

\section{RESULTS}

Table 1 displays the socio-demography profile of the respondents. A large majority of the respondents (82.1\%) were male. More than one third of the respondents (34.2\%) were in the group age of 41-50 years. Slightly more than half of the respondents (52.5\%) hold SPM/SPMV level of education while another $20.4 \%$ of them hold pre university and university qualification. A total of $35.5 \%$ of the respondents were self employed while $25.8 \%$ of them were among retirees and housewives. More than one third of the respondents (37.1\%) had monthly income of RM1501 or more in a month and the mean score of monthly income recorded was RM1, 507.90. It is interesting to note that slightly more than three quarter of the respondents $(77.5 \%)$ have held the position in VDSC for more than 6 years. Nearly two thirds of the respondents $(61.6 \%)$ were the committee members compared to $38.8 \%$ of the respondents who were top management members. Majority of the respondents can be considered as "senior villagers" as $62.5 \%$ had stayed in their villages for more than 30 years while slightly more than one third of the respondents (37.5\%) had stayed for 30 years or less. This study has come out with an early positive indicator where the mean score recorded for computer usage in a week was 11.07 hours and mean score recorded for internet usage in a week was 9.05 hours. Each of the zone studied in this study was represented by an equal number of respondents (25.0\%).

Mean summated score on ICT usage among the respondent was computed using a ten item instrument. The summated scores were then divided into three levels of ICT usage namely low (1-3.33), moderate (3.34-6.67) and high (6.68-10.0). Comparatively, a large portion of the respondents $(43.8 \%)$ showed low ICT usage. Moderate and high ICT usage works showed about equal level percentage, $27.4 \%$ and $28.8 \%$ respectively. The overall level of ICT usage among VDSC members was moderate as depicted by 4.47 mean summated score (Table 2).

Detail distribution of the ten items to measure ICT usage is presented in Table 3. Mean score for each item was used to describe the most frequent task in ICT usage instrument. The statement of "Preparing letters, memo, minutes meeting and reminder "recorded the highest mean score $(\mathrm{M}=4.98)$ the second highest mean score was recorded by the statement of "Preparing village profile" $(\mathrm{M}=4.92)$, followed by the statement of "Preparing monthly report regarding administration and village development” $(M=4.84)$. The lowest mean score was recorded by the statement of "Sending information required to related agency through egovernment services” $(M=3.43)$. 
J. Social Sci., 7 (2): 113-119, 2011

Table 1: Socio-demography data of the respondents

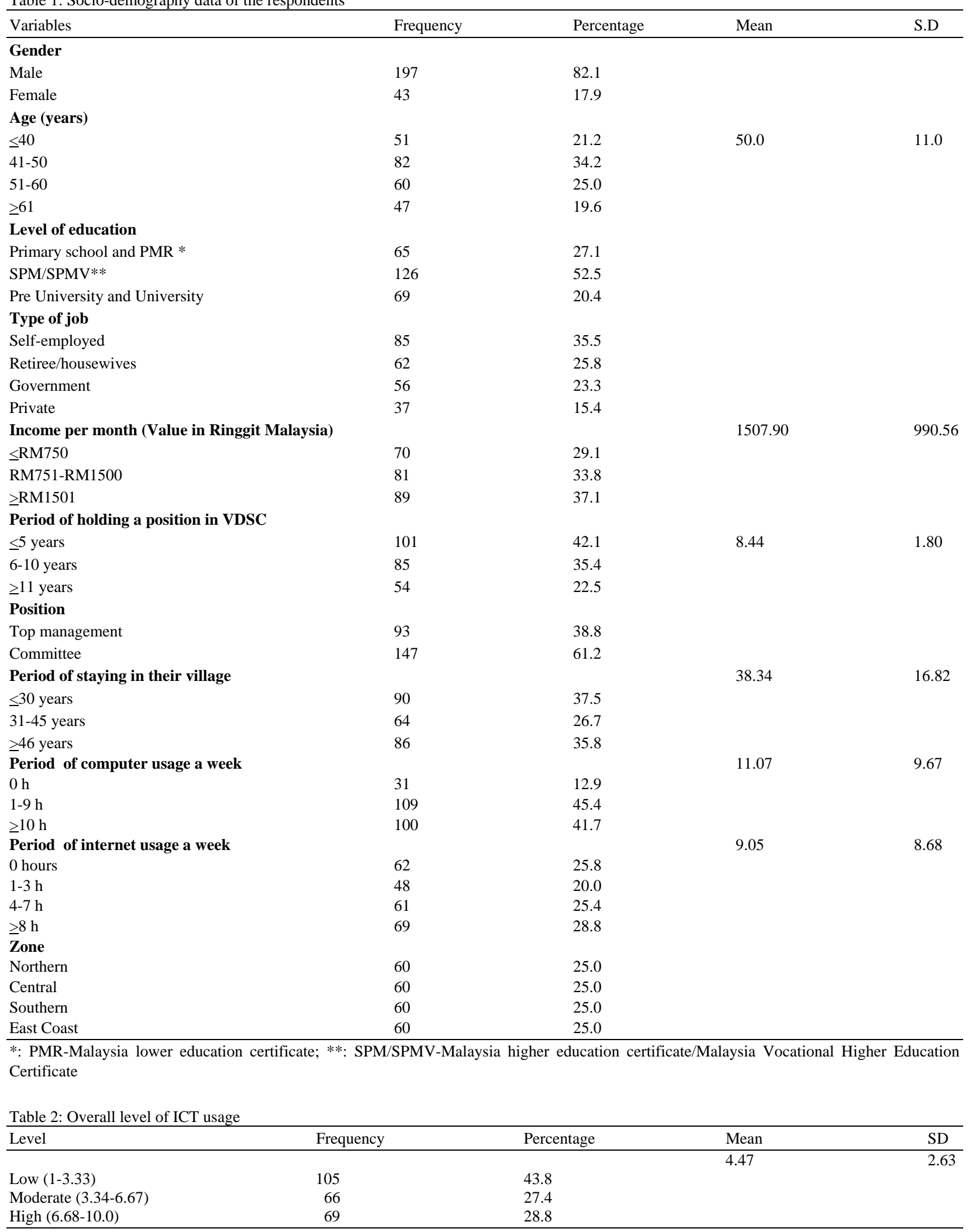


J. Social Sci., 7 (2): 113-119, 2011

Table 3: Percentage distribution of ICT usage items

\begin{tabular}{|c|c|c|c|c|c|c|c|c|c|c|c|c|}
\hline Statement & 1 & 2 & 3 & 4 & 5 & 6 & 7 & 8 & 9 & 10 & Mean & SD \\
\hline $\begin{array}{l}\text { Preparing letters, memo, minutes } \\
\text { meeting and reminder }\end{array}$ & 18.8 & 12.5 & 10.0 & 7.9 & 6.7 & 5.8 & 9.6 & 9.2 & 11.7 & 7.9 & 4.98 & 3.12 \\
\hline Preparing village profile & 18.8 & 8.3 & 16.2 & 7.1 & 7.1 & 5.0 & 8.8 & 12.5 & 10.0 & 6.2 & 4.92 & 3.03 \\
\hline $\begin{array}{l}\text { Preparing monthly report regarding } \\
\text { administration and village development }\end{array}$ & 17.9 & 15.0 & 11.2 & 6.2 & 4.6 & 6.7 & 10.4 & 15.0 & 7.5 & 5.4 & 4.84 & 3.02 \\
\hline Preparing timeline for activities scheduled & 20.0 & 13.3 & 9.6 & 7.5 & 7.9 & 8.3 & 10.8 & 12.9 & 5.8 & 3.8 & 4.64 & 2.88 \\
\hline g schedule for & 21.2 & 13.3 & 10.0 & 6.2 & 10.0 & 7.5 & 8.3 & 11.7 & 7.9 & 3.8 & 4.58 & 2.93 \\
\hline $\begin{array}{l}\text { Preparing sources for billboard at VDSC } \\
\text { room or mosque }\end{array}$ & 19.2 & 12.9 & 13.8 & 7.5 & 6.2 & 7.9 & 14.2 & 11.7 & 3.8 & 2.9 & 4.50 & 2.77 \\
\hline Preparing village data and statistic & 18.3 & 16.2 & 13.8 & 4.2 & 11.2 & 6.7 & 9.6 & 12.1 & 3.3 & 4.6 & 4.45 & 2.82 \\
\hline $\begin{array}{l}\text { Communicating with VDSC members } \\
\text { and village community }\end{array}$ & 28.3 & 10.8 & 9.2 & 7.1 & 7.5 & 3.3 & 7.9 & 13.3 & 7.9 & 4.6 & 4.43 & 3.10 \\
\hline $\begin{array}{l}\text { Preparing presentation using } \\
\text { Microsoft power point }\end{array}$ & 32.9 & 14.2 & 9.2 & 5.4 & 7.5 & 5.4 & 7.1 & 8.8 & 6.2 & 3.3 & 3.90 & 2.96 \\
\hline $\begin{array}{l}\text { Sending information required to related agency } \\
\text { through e-government services }\end{array}$ & 37.1 & 12.1 & 11.7 & 7.5 & 7.9 & 7.9 & 5.4 & 5.0 & 2.5 & 2.9 & 3.43 & 2.65 \\
\hline
\end{tabular}

\begin{tabular}{lrlll}
\multicolumn{6}{l}{ Table 4: Level of technology acceptance model variables } \\
\hline Variables & Frequency & Percentage & Mean & SD \\
\hline Perceive ease of use & & & $\mathbf{6 . 8 8}$ & $\mathbf{2 . 4 3}$ \\
Low (1-3.33) & 33 & 13.8 & & \\
Moderate (3.34-6.67) & 75 & 31.2 & & \\
High (6.68-10.0) & 132 & 55.0 & & \\
Perceived usefulness & & & $\mathbf{6 . 5 0}$ & $\mathbf{2 . 4 5}$ \\
Low (1-3.33) & 29 & 12.1 & & \\
Moderate (3.34-6.67) & 50 & 20.8 & & \\
High (6.68-10.0) & 161 & 67.1 & & \\
Attitude & & & $\mathbf{5 . 9 1}$ & $\mathbf{2 . 4 8}$ \\
Low (1-3.33) & 45 & 18.8 & & \\
Moderate (3.34-6.67) & 85 & 35.4 & & \\
High (6.68-10.0) & 110 & 45.8 & & \\
\hline
\end{tabular}

Distribution of the three independent variables is presented in Table 4. Mean summated score was computed for perceive ease of use, perceive usefulness and attitude. The scores were transferred into three levels- low, moderate and high for scores between 13.33, 3.34-6.67 and $6.68-10.0$ respectively. Perceive ease of use recorded the highest mean score $(M=6.88)$, followed by perceived usefulness $(\mathrm{M}=6.50)$ and attitude $(M=5.90)$. It also can be noted that more than half of the respondents $(55.0 \%)$ have a high level of perceive of use towards ICT usage. A total of $67.1 \%$ of the respondents showed a high level of perceive usefulness towards ICT usage while more than two fifths of the respondents (45.8\%) deposited a high level of attitude towards ICT usage.

Pearson correlation was used to examine relationship between the three variables in TAM and ICT usage. As been depicted from Table 5, all of the three variables studied correlate positively and significantly with ICT usage. Based on Guilford rules of thumb, the strength magnitude of relationship between the three variables and ICT usage was moderate and substantial. The correlation coefficient range from the highest 0.658 for attitude to the lowest .520 for perceive ease of use. $\underline{\text { Table 5: Relationship between ICT usage and selected TAM variables }}$

\begin{tabular}{lll}
\hline Variables & $\mathrm{r}$ & $\mathrm{p}$ \\
\hline Attitude & 0.658 & 0.0001 \\
Perceive ease of use & 0.520 & 0.0001 \\
Perceive usefulness & 0.450 & 0.0001 \\
\hline
\end{tabular}

Table 6: Factors that contribute to ICT usage

\begin{tabular}{lccc}
\hline Independent variables & Beta & $\mathrm{t}$ & $\mathrm{p}$ \\
\hline Constant & 0.000 & 0.719 & 0.0001 \\
Attitude & 0.631 & 8.125 & 0.0001 \\
Perceive ease of use & 0.144 & 1.969 & 0.0500 \\
Perceive usefulness & -0.105 & -1.394 & 0.1650 \\
\hline $\mathrm{R}=0.666, \mathrm{R}^{2}=0.443$, Adjusted $\mathrm{R}^{2}=0.436, \mathrm{~F}=62.664, \mathrm{p}=0.0001$
\end{tabular}

While Pearson correlation describes relationship between two variables, Multiple Linear Regression can examine relationship between multiple independent variables on dependent variable. Specifically, the enter regression analysis was employed to determine predictor variables that significantly contribute towards ICT usage. Based on the results presented in Table 6, it can be portrayed that two independent variables provide the best prediction for ICT usage and explained about $44 \%$ of variance in ICT usage. These two variables are attitude and perceive ease of use. However, another variable studied, perceive usefulness not significantly contribute to ICT usage

\section{DISCUSSION}

Based on the results gained, attitude was found as the main contributor to ICT usage among VDSC. Positive attitude is essential to motivate someone to learn something and it will smooth the ICT learning and usage process (Zulkifli and Raja Maznah, 1994). This is not surprising as it is in tandem with number of previous studies (Chau, 2001; Shiro, 2008; Dixon, 2009; Zhang and Aikman, 2009; Mahmood et al., 2000). Positive attitude towards ICT usually will drive 
to higher ICT usage while negative attitude towards ICT will drive to lower ICT usage. As been mentioned, this study has found that perceive ease of use is an essential element for ICT usage among VDSC. This is not surprising as it is consistent with number of previous studies (Meso and Musa, 2008 and Venkatesh and Davis, 1996). Ndubisi (2003) through her study has concluded that perceive ease of use have a direct influence on ICT usage. Moreover, according to Ndubisi (2003), perceive ease of use in using ICT will have important influence over community decision whether to adopt or reject the ICT usage. Related to this study, VDSC who perceive ICT is easy to use will adopt the ICT more and those who perceive the ICT is difficult to use will refuse to use it. This study reveals that perceive usefulness is an important element to influence ICT usage among VDSC and it supported what previous studies have proved (Bennett and Bennett, 2003; Mohd Safar and Ali, 2009). Bennet and Bennet (2003), for example have stressed that people who perceive that ICT have more benefits are willing to integrate it in their study. Similar to this study, the perceive usefulness also can be seen to affect the adoption of ICT as been proved by Rogers (2003). The perceive usefulness of ICT according to Rogers will speed up people adoption of ICT usage, this is because ICT offers a lot of advantages such as fasten people works, becoming cheaper nowadays and bigger storage capability. From this study, to strengthen VDSC attitude, perceive ease of use and perceive usefulness towards ICT usage works, it is recommended that responsible agencies can take initiative to enhance the ICT usage among VDSC by practicing house to house training. In this type of training, the responsible agencies will assign their officers to the VDSC house for the purpose of educating the VDSC on ICT usage. To have the impact, of course the training must be frequent. To have frequent training skills is important as it has been emphasized by Raymond (1988) and Carey et al. (2002), where they revealed that the number of training skills attended have a significant effect on the computer usage. Besides, by having the training skills, it will inform the VDSC on how important the ICT is to their study and more importantly to their village development.

\section{CONCLUSION}

It can be concluded that VDSC have a moderate level of ICT usage while majority of them are using ICT for the purpose of Preparing letters, memo, minutes meeting and reminder. The main objective of this study was fulfilled by concluding that VDSC with a high level of attitude, perceive ease of use and perceive usefulness will have higher level of ICT usage. Based on this, it can be concluded, TAM that was used to explain ICT usage can be applied within the Malaysian rural setting. Besides, attitude was found as the major contributor towards ICT usage among VDSC.

\section{REFERENCES}

Argawal, R. and J. Prasad, 1999. Are individual differences germane to the acceptance of new information Technologies? J. Dec. Sci., 30: 361-391. DOI: 10.1111/j.1540-5915.1999.tb01614.x

Bennett, J. and L. Bennett, 2003. A review of factors that influence the diffusion of innovation when structuring a faculty training program. Int. Higher Edu., 6: 53-63. DOI: 10.1016/S10967516(02)00161-6

Carey, J., I. Chisholm and L. Irwin, 2002. The impact of access on perceptions and attitudes towards computers: An international study. J. Educ. Media Int., $\quad 39$ : 223-235. DOI: $10.1080 / 09523980210166431$

Chau, P.Y., 2001. Influence of computer attitude and self-efficacy on IT usage behavior. J. End User Comput., $\quad$ 13: 26-33. DOI: 10.4018/joeuc.2001010103

Davis, F.D., R.P. Bagozzi and P.R. Warshaw, 1989. User acceptance of computer technology: A comparison of two theoretical models. Manage. Sci., 35: 982-1003. DOI: 10.1287/mnsc.35.8.982

Dixon, K.C., 2009. Attitudes towards ICT based interaction: A bachelor of education case studies. School of Education, Curtin University of Technology Perth, Australia. http://www.aare.edu.au/09pap/dix091331.pdf

Ghazy, M.M.E.D., W.M.E. Senousy, A.M.A. Aatty and M. Kamel, 2008. Performance evaluation of a waste stabilization pond in a rural area in Egypt. Am. J. Environ. Sci., 4: 316-325. DOI: 10.3844/ajessp.2008.316.325

Fishbein, M. and I. Ajzen, 1975. Belief, Attitude, Intention and Behavior: An Introduction to Theory and Research. 1st Edn., Addison-Wesley Pub., USA., ISBN: 0201020890, pp: 578.

Mahmood, M.A., J.M. Burn, L.A. Gemoets and C. Jacquez, 2000. Variables affecting information technology end-user satisfaction: A meta-analysis of the empirical literature. Int. J. Hum. Comput. Stud., 52: 751-771. DOI: 10.1006/ijhc.1999.0353 
Meso, P. and P.F. Musa, 2008. Extending the ICT technological culturation model: The role of accessibility and perceived socio-economic prospects on ICT diffusion. Proceedings of the PreICIS Workshop by SIG on Global Development, (WSIGGD' 08), Georgia State University, $\quad$ Paris, $\quad$ pp: 1-21 http://www.globdev.org/files/33-Paper-MesoTech-Culturation.pdf

Michiels, S.I. and L. Van Crowder, 2001. Discovering the "Magic Box": Local Appropriation of Information and Communication Technologies (ICTs). Sustainable Development Department (SD) Food and Agriculture Orgnization of the United Nations (FAO). http://www.fao.org/sd/2001/kn0602_en.htm

Mohd Safar, H. and S. Ali, 2009. Factors affecting sustainability of internet usage among youth. J. Elect. Library, 28: 300-313. DOI: 10.1108/02640471011033657

Ndubisi, N.O., 2003. Women entrepreneurs and IT usage: The impact of traits. J. Bus. Dev. Nat., 7: 112-147. http://www.ewp.rpi.edu/jbdn/jbdnv705.pdf

Rahman, M.A., M.U. Mahfuz, K.M. Ahmed and R.M.A.P. Rajatheva, 2005. ICT based sustainable rural business opportunities in developing countries: a wireless-networked RCP-RAP approach. Am. J. Applied Sci., 2: 1256-1260. DOI: 10.3844/ajassp.2005.1256.1260
Raymond, L., 1988. The impact of computer training on the attitudes and usage behavior of small business manager. J. Small Bus. Manage., 26: 1-8. http://www.amazon.com/computer-trainingattitudes-behavior-managers/dp/B0008MEXAS

Rogers, E.M., 2003. Diffusion of Innovations. 5th Edn., The Free Press, New York, ISBN-10: 0743258231, pp: 576.

Uesugi, S., 2008. A case study of DIY ICT. J. Inform., 10: 46-60. DOI: 10.1108/14636690810887535

Venkatesh, V. and F.D. Davis, 1996. A theoretical extension of the technology acceptance model: Four longitudinal field studies. J. Manage. Sci., 46: 186-204. DOI: 10.1287/mnsc.46.2.186.11926

Venkatesh, V. and M.G. Morris, 2000. Why don't men ever stop to ask for directions? Gender, social influence and their role in technology acceptance and usage behavior. J. MIS Q., 24: 115-139. DOI: $10.2307 / 3250981$

Zhang, $\mathrm{P}$ and S. Aikman, 2009. Attitudes in ICT Acceptance and Use. Human-Comput. Interaction. Design Usabil., 4550: 1021-1030. DOI: 10.1007/978-3-540-73105-4_112

Zulkifli, A.M. and R.H. Raja Maznah, 1994. Attitudes, knowledge and previous computer experience of teacher trainees in the diploma of education program at the University Malasia. J. Educ., 16: 1-9. http://www.scipub.org/fulltext/jss/jss511-8.pdf 